\title{
Therapeutic efficacy of chloroquine and primaquine for Plasmodium vivax malaria treatment in southeast Iran
}

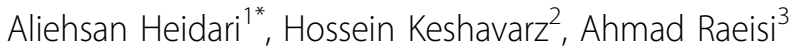 \\ From Challenges in malaria research \\ Basel, Switzerland. 10-12 October 2012
}

\begin{abstract}
Background
Plasmodium vivax is the main cause of malaria infection in Asian, Central and South American countries [1]. It accounts for more than $90 \%$ annually of the reported malaria cases in Iran [2]. Plasmodium vivax resistant to chloroquine has emerged in some regions of Asia and resistance or tolerance to primaquine has been demonstrated in several countries $[3,4]$. The aim of this study was to determine the therapeutic efficacy of chloroquine and primaquine for Plasmodium vivax malaria treatment in southeast Iran.
\end{abstract}

\section{Material and methods}

A total of randomly selected 270 patients with confirmed $P$. vivax infection participated in 28-day in vivo study that extended for 2 years for detecting relapse infection. Chloroquine and primaquine were administrated during 3 days and 8 weeks respectively in 2010 . The thick and thin film blood smears were screened for malaria parasites by microscopy. The nested PCR was applied using the Plasmodium 18 subunit ribosomal ribonucleic (Ssr RNA) genes for detecting mixed infections and diagnosis of parasites in the samples with low parasite on days monitoring the drug resistance.

\section{Results}

Fever resolved on the first day in all subjects. Microscopy findings showed that $P$. vivax was cleared in $15 \%$, $50 \%, 95 \%$, and $100 \%$ of patients on days $1,2,3$ and 4 , respectively. All 270 subjects showed $\sim 120$ Bp band in the nested PCR which was indicative of $\mathrm{P}$. vivax malaria on the zero days. Six patients $(2.2 \%)$ had specific

'Dept. of Pathobiology, School of Medicine, Alborz University of Medical Sciences, Karaj, Iran

Full list of author information is available at the end of the article
P. vivax band in nested PCR on day 5 . No recurrence was observed on days 7, 14 and 28 in thick blood smear and nested PCR. Mean ( \pm standard deviation) parasite clearance time was $2.41( \pm 0.8)$ days. Two patients had $P$. vivax malaria clinical and parasitological infection following 8 and 12 months after primary $P$. vivax malaria infection.

\section{Conclusions}

The findings of this study showed susceptibility of $P$. vivax to chloroquine in South east Iran. This finding is compatible with results of neighboring countries Pakistan and Afghanistan. Nested PCR was a suitable assay to determine exact malaria parasite clearance time in our study. The further investigation is being conducted in two reinfection cases by PCR -Single strand conformational polymorphism method to differentiate between relapse and new $P$. vivax infection.

\footnotetext{
Author details

${ }^{1}$ Dept. of Pathobiology, School of Medicine, Alborz University of Medical Sciences, Karaj, Iran. ${ }^{2}$ Dept. of Medical Parasitology and Mycology, School of Public Health, Tehran University of Medical Sciences, Iran. ${ }^{3}$ Dept. of Medical Entomology and Vector Control, School of Public Health, Tehran University of Medical Sciences, Iran.

Published: 15 October 2012

References

1. Naing C, Kyan A, Khin Wine D, Wah MJ: Efficacy and safety of Chloroquine for treatment in patients with uncomplicated Plasmodium vivax infections in endemic countries. Trans R SOC Trop Med Hyg 2010, 104:695-705

2. WHO: Malaria profile of Iran. 2010, available: www.who.int/malaria/ publications/country-profiles/profile_irn_en.pdf.

3. Awab GR, Pukrittayakamee $S$, Immwong M, Dondorp AM, Woodrow CL, Lee SJ, Day NPG, Singhasivanon P, White NJ, Kaker F: DihydroartemisininPiperaquine versus Chloroquine to treat vivax malaria in Afghanistan: an open randomized, non -inferiority trial. Malar Journal 2010, 9:105.
} 
4. Yeshwondim AK, Tekle AH, Dengela DO, Yohannes AM: Therapeutic efficacy of chloroquine and chloroquine plus primaquine for the treatment of Plasmodium vivax in Ethiopia. Acta Trop 2010, 113:105-113.

doi:10.1186/1475-2875-11-S1-P45

Cite this article as: Heidari et al.: Therapeutic efficacy of chloroquine and primaquine for Plasmodium vivax malaria treatment in southeast Iran. Malaria Journal 2012 11(Suppl 1):P45

Submit your next manuscript to BioMed Central and take full advantage of:

- Convenient online submission

- Thorough peer review

- No space constraints or color figure charges

- Immediate publication on acceptance

- Inclusion in PubMed, CAS, Scopus and Google Scholar

- Research which is freely available for redistribution

Submit your manuscript at www.biomedcentral.com/submit
C Biomed Central 